University of Nebraska - Lincoln

DigitalCommons@University of Nebraska - Lincoln

Entomology Papers from Other Sources

Entomology Collections, Miscellaneous

2015

Comparison of Host-Seeking Behavior of the Filth Fly Pupal Parasitoids, Spalangia cameroni and Muscidifurax raptor (Hymenoptera: Pteromalidae)

E. T. Machtinger

University of Florida, irishtangerine@ufl.edu

C. J. Geden

USDA-ARS

P.E. Teal

USDA-ARS

N. C. Leppla

University of Florida

Follow this and additional works at: http://digitalcommons.unl.edu/entomologyother

Machtinger, E. T.; Geden, C. J.; Teal, P. E.; and Leppla, N. C., "Comparison of Host-Seeking Behavior of the Filth Fly Pupal Parasitoids, Spalangia cameroni and Muscidifurax raptor (Hymenoptera: Pteromalidae)" (2015). Entomology Papers from Other Sources. 118. http://digitalcommons.unl.edu/entomologyother/118

This Article is brought to you for free and open access by the Entomology Collections, Miscellaneous at DigitalCommons@University of Nebraska Lincoln. It has been accepted for inclusion in Entomology Papers from Other Sources by an authorized administrator of DigitalCommons@University of Nebraska - Lincoln. 


\title{
Comparison of Host-Seeking Behavior of the Filth Fly Pupal Parasitoids, Spalangia cameroni and Muscidifurax raptor (Hymenoptera: Pteromalidae)
}

\author{
E. T. MACHTINGER, ${ }^{1,2}$ C. J. GEDEN, ${ }^{3}$ P. E. TEAL, ${ }^{3}$ AND N. C. LEPPLA ${ }^{1}$
}

\begin{abstract}
Environ. Entomol. 44(2): 330-337 (2015); DOI: 10.1093/ee/nvu063
ABSTRACT The pupal parasitoids, Spalangia cameroni Perkins and Muscidifurax raptor Girault and Sanders, can be purchased for biological control of house flies Musca domestica L. and stable flies Stomoxys calcitrans (L.) (Diptera: Muscidae). Little is known about the odors involved in host-seeking behavior of these two species, so odors associated with house flies were investigated in the laboratory using a Y-tube olfactometer. Odor stimuli from house fly host puparia, larvae, pine-shavings bedding with horse manure, and developing flies in the pine-shavings-manure substrate were evaluated in bioassays using the two pteromalid species. In choice tests, naïve female S. cameroni were strongly attracted to odor from the substrate containing house fly larvae and secondarily from the uninfested substrate and substrate with puparia versus humidified and purified air. This species also selected the substrate with larvae versus the substrate with the house fly puparia or uninfested substrate. Muscidifurax raptor was attracted to odor from the substrate containing puparia, washed puparia, and substrate with puparia removed. The data suggest that coexistence between the two pteromalid parasitoids, S. cameroni and M. raptor, might be promoted by different host-seeking behavior.
\end{abstract}

KEY WORDS olfactometer, pteromalid, biological control, Musca domestica, Stomoxys calcitrans

\section{Introduction}

Spalangia cameroni Perkins and Muscidifurax raptor Girault and Sanders (Hymenoptera: Pteromalidae) are widely distributed filth fly ectoparasitoids (Taylor et al. 2006, Noyes 2014). These two species of pupal parasitoids are commercially available and often sold together to control house flies Musca domestica L. and stable flies Stomoxys calcitrans (L.), two pests of medical and veterinary importance. Although releases of pteromalid parasitoids as biological control agents for the control of pest muscoid flies associated with livestock have become more common in recent years (U.S. Department of Agriculture [USDA] 2006, Machtinger et al. 2012), their effectiveness has been variable (Meyer et al. 1990, Morgan and Patterson 1990, Geden et al. 1992, Andress and Campbell 1994, Petersen and Cawthra 1995, Weinzierl and Jones 1998, McKay and Gallowway 1999, Crespo et al. 2002, Skovgård and Nachman 2004). Inconsistent fly control using pteromalid pupal parasitoids may result partially from an incomplete understanding of their host-seeking behavior. Because $S$. cameroni and $M$. raptor often are released together, comparative studies of the host-seeking behavior of these two parasitoids that share the same habitat could help with understanding their capacity for coexistence

\footnotetext{
${ }^{1}$ Department of Entomology and Nematology, University of Florida, P.O. Box 110620, Gainesville, FL 32611.

${ }^{2}$ Corresponding author, e-mail: irishtangerine@ufl.edu.

${ }^{3}$ USDA-ARS, Center for Medical, Agricultural, and Veterinary Entomology, 1600 S. W. 23rd Dr., Gainesville, FL 32611.
}

and improve their effectiveness in augmentative biological control programs (van Dijken and van Alphen 1998, de Moraes et al. 1999).

Volatile semiochemicals emitted from house and stable fly larval and pupal habitat, fly development stages, or interactions with associated microorganisms may serve as kairomones that attract parasitoids to their hosts (Vinson 1976, 1981, Elzen et al. 1983, Noldus 1988, Godfray 1994, Omacini et al. 2001, Mbata et al. 2004, Schulz and Dickschat 2007). The ephemeral nature and patchy distribution of some habitats of developing filth flies poses a challenge for newly emerged, adult pupal parasitoids to locate hosts. Odors emanating from host habitats can serve as long-range stimuli that are often highly detectable, whereas odors directly from hosts are a more reliable indication of host presence, but are generally less detectable from a distance (Laing 1937, Vet et al. 1991, Voss et al. 2009).

Early studies conducted on the effects of chemical stimuli on host finding in pteromalid filth fly parasitoids has produced inconsistent results. Some species are attracted to host habitat (Laing 1937), but more attracted to a combination of hosts and habitat (Edwards 1954, Wylie 1958, Stafford et al. 1984). Some species seem to use cues directly from the hosts, and host habitat without hosts is repellent (McKay and Broce 2003).

Understanding the host-seeking behavior of $S$. cameroni and $M$. raptor could increase the effectiveness of augmentative biological control programs by improving release and monitoring techniques. Taxonomic genus bias has been recorded with common 
monitoring methods; Muscidifurax spp. being recovered more frequently in laboratory-reared sentinel puparia, whereas Spalangia spp. are more abundant in wild-collected puparia (Petersen and Watson 1992). Analysis of odor-mediated behavior associated with host location could lead to monitoring strategies that are tailored to each parasitoid.

This study was focused on the responses of female $S$. cameroni and $M$. raptor to odors associated with developing hosts in an equine-generated substrate. Responses to odors of hosts as larvae or pupae with and without development substrate were tested in a Ytube olfactometer.

\section{Materials and Methods}

House Fly and Parasitoid Rearing. House flies were obtained from a colony maintained at the USDAARS, Center for Medical, Agriculture and Veterinary Entomology (CMAVE) and reared as described in Machtinger and Geden (2013). Parasitoids used for this study were from colonies of $S$. cameroni and $M$. raptor established in 2012 from a source population on a dairy in Gilchrist County, FL. Colony maintenance consisted of providing parasitoids with 2-d-old house fly pupae as hosts at a host: parasitoid ratio of 5:1 twice weekly in $17.5 \times 17.5 \times 17.5$-cm Bug Dorms (MegaView Science, Taiwan) held at $25^{\circ} \mathrm{C}$ and $80 \%$ relative humidity $(\mathrm{RH})$ under constant light.

Experimental Substrates. The substrate used for the choice tests was 3-d-old pine shavings bedding (0.1-0.3-cm long) mixed with horse manure and urine. Both $S$. cameroni and $M$. raptor locate hosts in this medium (Pitzer et al. 2011, Machtinger and Geden 2013). The substrate was collected from a private equine facility in Reddick, FL. Shavings and manure were collected separately and frozen at $-20^{\circ} \mathrm{C}$ for a minimum of $1 \mathrm{wk}$ prior to testing to kill any existing arthropods. A standardized amount of substrate was used for each treatment $(20 \mathrm{~g}$ total, $15 \mathrm{~g}$ of horse manure and $5 \mathrm{~g}$ pine shavings). This substrate was placed in a 5.5 -oz plastic cup measuring $6 \mathrm{~cm}$ in height $\times 7.5 \mathrm{~cm}$ in diameter, hydrated to $70 \%$ by weight (Machtinger 2011), and mixed thoroughly. For a treatment with developing house flies, 30 eggs were applied to a moistened cloth placed on the surface of the substrate (Machtinger 2011). Substrate was also tested without developing fly larvae and puparia. Cups were covered with muslin, sealed with plastic rim lids, and maintained at $27^{\circ} \mathrm{C}$ and $80 \% \mathrm{RH}$ under constant light. The entire contents of each cup were used only once for each test.

By random assignment, a variety of odor stimuli were presented in choice tests to both $S$. cameroni and M. raptor. The following odor treatments were tested at $4 \mathrm{~d}$ after initial set up in the cups: 1) substrate without developing house flies (uninfested substrate), 2) substrate with larvae that had developed from eggs to third instar (substrate with larvae), and 3) substrate in which the larvae had developed to third instar but were removed (substrate, larvae removed). Additionally, odor treatments were conducted with house fly puparia at $8 \mathrm{~d}$ after cup establishment, including substrate with house flies that had developed from eggs to puparia (substrate with puparia) and substrate in which house flies had developed to puparia but the puparia were removed (substrate, puparia removed). Larvae (washed larvae) and puparia (washed puparia) tested separately from substrate were removed from their respective substrates the morning of each bioassay. Individual larvae or pupae were rinsed twice with distilled water and air dried a minimum of $1 \mathrm{~h}$ prior to testing.

Substrate Bioassays. Bioassays were conducted at the USDA-ARS, CMAVE in an isolated laboratory illuminated with a $13 \mathrm{w}$ CFL red light (195 lumens). They were performed using a glass Y-tube olfactometer constructed with a $16-\mathrm{cm}$-long central arm that was connected to two 8.5-cm-long lateral arms. The central and lateral arms were $2 \mathrm{~cm}$ in diameter. A removable 8$\mathrm{cm}$-long glass adaptor was inserted into each of the lateral arms and caped with 100-mesh plastic screen to prevent parasitoids from accessing the odor sources. Each glass adaptor was connected with Teflon tubing to a 35 -cm-long $\times 4$-cm-diameter glass chamber used to hold odor treatments for testing. Compressed air was humidified and purified with charcoal using a 2port humidity and air delivery system (Model \# OLFM-HAPS-ZAFMIC, Analytical Research Service, Inc., Gainesville, FL). In preliminary tests, the two parasitoid species differed in behavior movement with varying airspeed, so airflow was optimized for each species using a flowmeter set at $200 \mathrm{ml} / \mathrm{min}$ for $S$. cameroni and $130 \mathrm{ml} / \mathrm{min}$ for $M$. raptor (McKay and Broce 2003). The olfactometer was placed in a $47.5 \times 47.5 \times 47.5-\mathrm{cm}^{3}$ Bug Dorm (MegaView Science, Taiwan) with nylon (150 mesh) sides. The bug dorm sides were covered with black plastic to eliminate lateral light from the test area.

Parasitoids were standardized according to the protocol established by Mandeville and Mullens (1990). Male and female parasitoids were held in a $17.5 \times 17.5 \times 17.5-\mathrm{cm}^{3}$ bug dorm without hosts and provided with a $10 \%$ sucrose solution for $24 \mathrm{~h}$ prior to the bioassays. S. cameroni is autogenous, emerging with fully developed eggs (Gerling and Legner 1968, Morgan et al. 1989, King and King 1994), and disperses quickly after emerging (King 1990), so was tested at 1 d old. In preliminary tests, $M$. raptor required an additional $48 \mathrm{~h}$ before responding to odor treatments, so this species was held in the same conditions but tested at $3 \mathrm{~d}$ old. Both species were held in the bioassay room at $25^{\circ} \mathrm{C}$ and $80 \% \mathrm{RH}$ in normal room light during the holding period.

Females were separated from males by immobilizing groups on a cooling table the morning of the bioassay and placing them in individual size 00 gelatin capsules. Individual capsules were opened and the parasitoids transferred to a 7 -cm- $\times 1.5$-cm-diameter tubular glass inlet adaptor to serve as a release chamber. The open end of the adaptor was covered with parafilm, and the parasitoid was given a minimum of 5 min to acclimate to the chamber to avoid an escape response. The chamber containing the wasp then was attached to the olfactometer with established airflow. The Y-tube was 
positioned horizontally for S. cameroni but vertically for $M$. raptor because this species was more responsive with the vertical orientation and tested for $5 \mathrm{~min}$. Parasitoids were scored as making a choice when they remained beyond a mark located $2 \mathrm{~cm}$ from the end of the Y-tube for 15 consecutive seconds. The latency time from initiation of the replicate to the parasitoid making a choice was recorded. If a parasitoid failed to make a choice within $5 \mathrm{~min}$, it was removed and recorded as no choice. Tests were continued until 10 parasitoids made a choice for every treatment. Parasitoids that did not make a choice, varying between one and three parasitoids per odor treatment, were not included in the analysis. To ensure that wasps had no bias in movement toward either arm, the Y-tube was flipped for every other female. After each replicate, the olfactometer and associated glassware were washed thoroughly with water, rinsed with acetone, and allowed to dry for a minimum of $1 \mathrm{~h}$ before reuse (McKay and Broce 2003). Ten parasitoids were tested individually for each odor source in one arm of the Ytube and clean air or another odor source in the other arm. Each odor test was replicated 10 times (total parasitoids, $n=100$ ), each using a different generation of parasitoids.

Statistical Analysis. Odor treatments were tested in random order once to complete a block for each replication and tests conducted on different days. All odor treatments were randomly tested. Ten odor treatment combinations were shared between $S$. cameroni and $M$. raptor. Additional odor sources were tested for each individual species to further verify preferences. Initial analysis of treatment blocks (responses to individual odor sources) did not reveal replication effects, so data were pooled for each treatment. A chi-square goodness-of-fit test was used to determine conspecific differences in choice between odor sources. The responses to odors were compared between species using Fisher's exact test (FET). To analyze the response time of females to a given odor stimulus, data were subjected to a one-way ANOVA and presented means were separated within species using Tukey's HSD. Time data were subjected to $\log$ transformations for statistical analysis and back transformed for presentation in Table 2. In all cases, the level of significance testing was $\alpha=0.05$. Statistical analysis was performed using JMP (v. 11, SAS Institute, Cary, NC.).

\section{Results}

Given a choice, the two pteromalid species, $S$. cameroni and $M$. raptor, selected different combinations of house fly larval substrate with and without fly larvae or puparia versus hydrated and purified clean air (Fig. 1). A highly significant number of S. cameroni moved toward the Y-tube arm with substrate containing house fly larvae versus clean air (Chi-square test: $\left.\chi^{2}=43.56, P=<0.0001\right)$ but the parasitoid also was attracted to uninfested substrate $\left(\chi^{2}=6.76\right.$, $P=0.0093), \quad$ substrate with puparia $\left(\chi^{2}=6.76\right.$, $P=0.0093)$, and substrate with puparia removed $\left(\chi^{2}=12.96, P=0.0003\right)$ versus clean air. S. cameroni did not differentiate between the washed larvae, washed puparia, and the substrate with puparia removed versus the clean air. Unlike S. cameroni, $M$. raptor did not distinguish between the substrate with larvae and the clean air control $(P=0.0001$; FET). Similarly, $M$. raptor did not distinguish between the substrate and clean air control, but this species was attracted to the substrate with puparia over clean air $\left(\chi^{2}=11.56, P=0.0007\right)$. A significant number of $M$. raptor selected washed puparia $\left(\chi^{2}=5.76, P=0.0164\right)$, and substrate with the puparia removed $\left(\chi^{2}=4.00\right.$, $P=0.0455)$ versus clean air.

When odor treatments were compared against other odors, S. cameroni and M. raptor responded differently to shared treatments. Similar to the behavior exhibited against clean air, S. cameroni was significantly attracted to the substrate with larvae over the substrate with puparia $\left(\chi^{2}=11.56, P=0.0007\right)$, the washed larvae over the washed puparia $\left(\chi^{2}=4.84, P=0.0278\right)$, and the substrate with larvae over the uninfested substrate $\left(\chi^{2}=4.00, P=0.0455\right)$. M. raptor was more attracted to the substrate with puparia than the substrate with larvae $\left(\chi^{2}=4.00, P=0.0455\right)$, the washed puparia over the washed larvae $\left(\chi^{2}=4.84, P=0.0278\right)$, and the uninfested substrate over the substrate with larvae $\left(\chi^{2}=4.00, P=0.0455\right)$. All of these comparisons were significantly different between species (substrate with larvae vs. substrate with puparia: $P=0.0002$, FET; washed larvae vs. washed puparia: $P=0.0028$, FET; substrate with larvae vs. substrate: $P=0.0071, \mathrm{FET}$ ).

Additional choice tests were conducted to verify the preference for house fly larval substrate by $S$. cameroni and for puparia by $M$. raptor (Table 1). The number of $S$. cameroni that moved toward the substrate with developing larvae removed was significantly greater than to clean air or washed larvae. Female parasitoids did not differentiate between the substrate with larvae and the substrate with larvae removed or between the uninfested substrate and washed larvae. For M. raptor, preferences were shown for washed puparia versus substrate containing larvae or substrate with puparia removed, and for substrate with puparia versus uninfested substrate.

The response latency time was varied between treatments for $S$. cameroni $(F=2.20 ; \quad \mathrm{df}=9, \quad 90$; $P=0.0292)$; however, $M$. raptor was consistent across all odor tests (Table 2). The response time of $S$. cameroni to washed puparia versus clean air was significantly slower than the other odors, but this species responded most rapidly to the uninfested substrate versus substrate with larvae. M. raptor responded slowest to the substrate with larvae versus clean air and most rapidly to substrate with puparia removed or substrate that contained puparia versus clean air, although there were no statistically significant differences between odor tests for this species.

\section{Discussion}

This study showed that S. cameroni and M. raptor differed substantially in their responses to odors from house fly hosts and substrates associated with developing larvae and puparia. Although these two species 


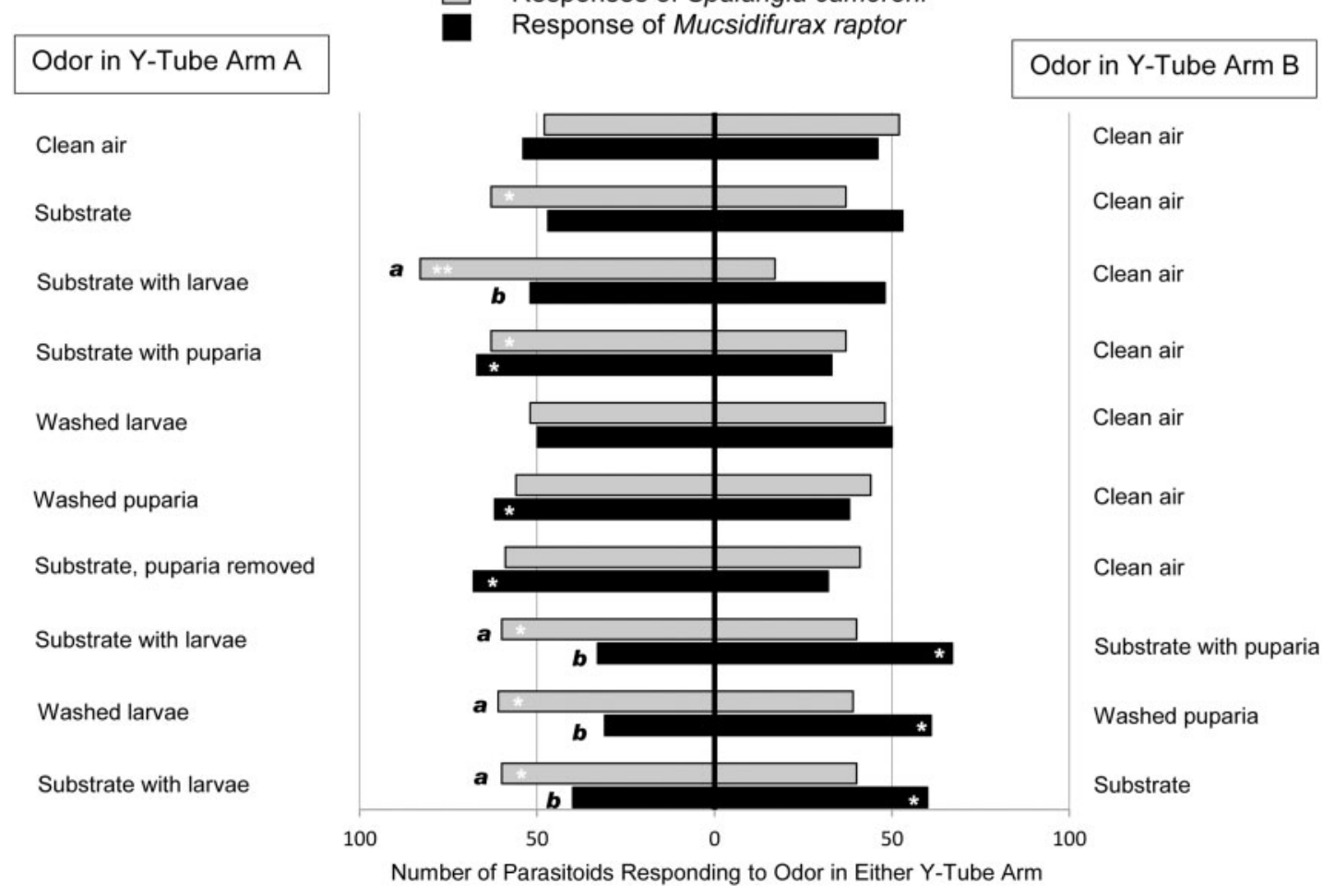

Fig. 1. Number of S. cameroni or M. raptor that responded in separate choice tests to odors from combinations of house fly larval substrate with and without fly larvae or puparia, or to clean air. The substrate consisted of $30 \mathrm{~g}$ of 3 -d-old pine shavings mixed with equine manure and urine. The horizontal bars show the number of wasps that choose either odor source within $5 \mathrm{~min}$ from the start of the test. Asterisks indicate significant differences within a choice test: $\chi^{2}$ test where $* P \leq 0.05$, $* * P \leq 0.001$. Letters denote significant differences in the number of the two species of parasitoids that responded to a specific odor combination (Fisher's exact test, $P \leq 0.05, N=100,10$ parasitoids $\times 10$ replicates).

Table 1. Number of S. cameroni and $M$. raptor that made a choice to odor emitted from a substrate consisting of 3-d-old pine shavings mixed with equine manure and urine only or used to rear house fly larvae and pupae, or washed larvae or pupae

\begin{tabular}{|c|c|c|c|c|c|c|}
\hline Parasitoid Species & Odor in Y-Tube Arm A ${ }^{a}$ & $N$ & Odor in Y-Tube Arm B ${ }^{b}$ & $N$ & $\chi^{2}$ & $P^{c}$ \\
\hline \multirow[t]{4}{*}{ S. cameroni $^{d}$} & Substrate, larvae removed & 80 & Clean air & 20 & 36.00 & $<0.0001^{* *}$ \\
\hline & Substrate, larvae removed & 70 & Washed larvae & 30 & 16.00 & $<0.0001^{* *}$ \\
\hline & Substrate with larvae & 57 & Substrate, larvae removed & 43 & 1.96 & 0.5485 \\
\hline & Substrate & 57 & Washed larvae & 43 & 1.96 & 0.5485 \\
\hline \multirow[t]{3}{*}{ M. raptor ${ }^{d}$} & Substrate with larvae & 36 & Washed puparia & 64 & 7.84 & $0.0051^{*}$ \\
\hline & Substrate with puparia & 63 & Substrate & 37 & 6.76 & $0.0093 *$ \\
\hline & Substrate, puparia removed & 40 & Washed puparia & 60 & 4.00 & $0.0455^{*}$ \\
\hline
\end{tabular}

${ }^{a}$ Odor treatments and substrate collection as described in depth in the methods.

${ }^{b}$ Clean air was humidified and purified.

${ }^{c}$ Asterisks indicate significant differences within a choice test: $\chi^{2}$ test where $* P \leq 0.05, * * P \leq 0.001(N=100,10$ parasitoids $\times 10$ replicates $)$.

${ }^{d}$ Colonies of S. cameroni and M. raptor established in 2012 were used in bioassays.

share some of the same habitats, their coexistence may rely on differences in host-seeking and relatively plastic foraging behavior (Vet et al. 1993, Wiskerke and Vet 1994, Geervliet et al. 1996, Cortesero et al. 1997, Harvey et al. 2013). S. cameroni was most attracted to odor stimuli originating from substrate and substrate with interactions with larvae, while $M$. raptor preferred odor associated with host puparia.

$S$. cameroni and $M$. raptor use many of the same habitats and hosts, but differences in life history and behavior, such as ovarian development, adult dispersal, and host seeking, enable them to coexist. S. cameroni was highly attracted to odor from substrates containing larvae. Similar positive responses to larvae in dry cattle manure over manure alone were observed with $S$. endius (Stafford et al. 1984), although the level of responsiveness depends on larval concentration. $S$. cameroni emerges as an adult with mature eggs and both males and females disperse rapidly in the laboratory, leaving the site of emergence within $3 \mathrm{~h}$ 
Table 2. Latency (seconds to choice) of $S$. cameroni and $M$. raptor that made a choice to odors emitted from a substrate consisting of 3-d-old pine shavings mixed with equine manure and urine only or used to rear house fly larvae and pupae, or washed larvae or pupae

\begin{tabular}{|c|c|c|c|}
\hline Odor in Y-Tube Arm A ${ }^{a}$ & Odor in Y-Tube Arm B ${ }^{b}$ & $\begin{array}{l}\text { S. } \text { cameroni }^{c} \text { time } \\
\text { to response }(\mathrm{s}) \text { Mean } \pm \mathrm{SE}^{d}\end{array}$ & $\begin{array}{l}\text { M. raptor }{ }^{c} \text { time to } \\
\text { response }(\mathrm{s}) \text { Mean } \pm \mathrm{SE}^{d}\end{array}$ \\
\hline Clean air & Clean air & $83.18 \pm 1.14 a b$ & $72.44 \pm 1.18 \mathrm{a}$ \\
\hline Substrate & Clean air & $89.13 \pm 1.17 \mathrm{ab}$ & $66.07 \pm 1.17 \mathrm{a}$ \\
\hline Substrate with larvae & Clean air & $83.18 \pm 1.10 \mathrm{ab}$ & $102.33 \pm 1.12 \mathrm{a}$ \\
\hline Substrate with puparia & Clean air & $93.33 \pm 1.09 \mathrm{ab}$ & $66.07 \pm 1.13 \mathrm{a}$ \\
\hline Washed larvae & Clean air & $107.15 \pm 1.06 \mathrm{ab}$ & $91.20 \pm 1.10 \mathrm{a}$ \\
\hline Washed puparia & Clean air & $112.20 \pm 1.09 \mathrm{a}$ & $74.13 \pm 1.16 \mathrm{a}$ \\
\hline Substrate, puparia removed & Clean air & $91.20 \pm 1.10 \mathrm{ab}$ & $58.88 \pm 1.14 \mathrm{a}$ \\
\hline Substrate with larvae & Substrate with puparia & $79.43 \pm 1.09 \mathrm{ab}$ & $87.09 \pm 1.21 \mathrm{a}$ \\
\hline Washed larvae & Washed puparia & $102.33 \pm 1.09 \mathrm{ab}$ & $69.18 \pm 1.16 \mathrm{a}$ \\
\hline Substrate & Substrate with larvae & $70.79 \pm 1.08 b$ & $89.13 \pm 1.11 \mathrm{a}$ \\
\hline \multicolumn{2}{|c|}{ Mean latency across all odor treatments (s) } & $90.37 \pm 1.03$ & $77.09 \pm 1.04$ \\
\hline
\end{tabular}

${ }^{a}$ Odor treatments and substrate collection as described in depth in the methods.

${ }^{b}$ Clean air was humidified and purified.

${ }^{c}$ Colonies of S. cameroni and M. raptor established in 2012 were used in bioassays.

${ }^{d}$ Means in a column followed by the same letter are not significantly different (Tukey's HSD test, $\alpha=0.05$ ).

(Myint and Walter 1990). Additionally, S. cameroni prefers to oviposit on young hosts, less than $24 \mathrm{~h}$ old (King 1997). Because it is autogenous, S. cameroni does not need to immediately locate host puparia and host-feed before ovipositing. Likely females can disperse quickly from emergence sites to habitats with developing larvae, ensuring the detection of newly pupariated hosts. Spalangia spp. are flexible in locating puparia within their habitats, parasitizing hosts at depths up to $10 \mathrm{~cm}$ (Rueda and Axtell 1985, Geden 2002). After locating the appropriate habitat, S. cameroni may encounter close-range or contact chemicals that expose newly formed puparia.

Unlike S. cameroni, the dispersal behavior of $M$. raptor after emergence is not known. The bioassays suggested that this species requires a short latency period before responding to odors, preferring odors associated with the puparia. The primary attraction to host puparia was observed with another Muscidifurax spp., Mucidifurax zaraptor Kogan and Legner (McKay and Broce 2003). M. zaraptor is somewhat repelled by fresh and aged poultry manure alone but strongly attracted to host puparia. Both M. zaraptor and M. raptor parasitize older hosts than S. cameroni (Mandeville et al. 1988; King 1997). Moreover, Muscidifurax spp. primarily parasitize puparia near the substrate surface (Legner 1977) and generally search only within $3 \mathrm{~cm}$ from the surface of the host habitat (Rueda and Axtell 1985, Geden 2002). Perhaps Muscidifurax spp. have evolved the ability to locate hosts based on specific odors and the flexibility to parasitize puparia of different ages.

Both S. cameroni and M. raptor had the strongest responses to odor produced either directly or indirectly by the developing hosts. S. cameroni was not attracted to odor produced by washed puparia or washed larvae against clean air, but was highly attracted to odor from the substrate containing larvae. Additionally, this species did not differentiate between the substrate with the larvae and the substrate after the larvae were removed, suggesting that the attractant was some interaction between the developing larvae and the substrate. Kairomones produced by bacteria and fungi have been documented as attractants for several species of parasitoids (Davis et al. 2013). It is not known if $S$. cameroni responds to volatile compounds emitted from larval frass or microbial activity associated with fly larvae; however, fungal volatiles have been found to be important for host location by several other species of pteromalids. Examples include the parasitoid of stored product pests Lariophagus distinguendus Forster (Steidle and Scholler 1997, 2002) and the bark beetle parasitoids Rhopalicus pulchripennis (Crawford) and Heydenia unica Cook and Davis (Steiner et al. 2007, Boone et al. 2008). In the absence of substrate with larvae, S. cameroni was attracted to uninfested substrate, whereas $M$. raptor was not, suggesting that there is some odor stimulus from the substrate alone. S. cameroni may be more adaptable than M. raptor in responding to odors but is most responsive to substrates that contain or previously contained developing larvae. Short- and long-range attraction to odors associated with hosts may be different for these two species of parasitoids.

Filth fly augmentative biological control programs will be more effective if the existing and released pteromalid parasitoids and their hosts can be monitored accurately and efficiently. Currently, parasitoid monitoring is conducted using laboratory-reared sentinel or wild-type collected puparia, but bias by host genera has been observed with Muscidifurax spp. being recovered more frequently from the sentinel puparia and Spalangia spp. from wild-type puparia (Petersen and Watson 1992). These field observations are consistent with the current study in which $M$. raptor was attracted to laboratory-reared puparia and substrates containing these puparia. When laboratory-reared puparia are placed in the field, they may be more attractive to $M$. raptor, whereas $S$. cameroni may only parasitize them by chance, unless they are placed near developing larvae. Although both S. cameroni and M. raptor oviposit on house fly puparia, monitoring techniques should 
integrate host puparia as well as developing larvae in substrate to recover the widest range of parasitoids.

Previous work examining competition between Muscidifurax spp. and Spalangia spp. has suggested that releases of these two taxanomic genera together may be beneficial and provide more control than a single species release (Rueda and Axtell 1985, Skovgård 2006). In some cases, biological control studies with introductions of multiple control agents have shown that often only a single agent is responsible for the control success (Myers et al. 1989, Denoth et al. 2002), likely because using multiple biological control agents has the potential to reduce the likelihood of control success through competitive exclusion (Ehler and Hall 1982). However, because of the complement of spatial separation in host seeking depth, age discrimination of pupal parasitization, and apparent differential hostseeking behavior, resource partitioning between these two species suggests that release in conjunction may provide cumulative control benefits. Fly control has been achieved by releasing both Muscidifurax spp. and S. cameroni (Geden and Hogsette 2006, Skovgård 2006, McKay et al. 2007). However, in all cases sentinel puparia alone were used to monitor parasitization, and control success was not measured against facilities with single-species releases. Further field studies are needed to assess the benefit of multiple-genera release of pupal parasitoids for filth fly control.

This study demonstrated that the two pupal parasitoid species, S. cameroni and $M$. raptor, use different strategies for host-seeking that may allow them to coexist in house fly habitats. Also, the negative effects of competition between these parasitoids might be mitigated by differences in their host utilization (Chesson 2000). Confirmation of the sources and identification of the volatile chemicals emanating from the developmental substrates, house fly larvae and puparia, or associated microorganisms that are involved in host-location by $S$. cameroni and M. raptor and further field studies assessing the benefit of multiple-genera releases should be explored to improve biological control using these parasitoids.

\section{Acknowledgments}

This research was supported by a USDA Southern Sustainable Agriculture and Research Education (SARE) award. We would like to thank Elizabeth Koller for her extensive help conducting the bioassays and Dana Johnson for maintaining laboratory colonies. We also appreciate the help of Rudy Strohschein on his design of the glassware used in the experiments.

\section{References Cited}

Andress, E. R., and J. B. Campbell. 1994. Innundative releases of pteromalid parasitoids (Hymenoptera: Pteromalidae) for the control of stable flies, Stomoxys calcitrans (L.) (Diptera: Muscidae) at confined cattle installations in west central Nebraska. J. Econ. Entomol. 87: 714-722.

Boone, C. K., D. L. Six, Y. Zheng, and K. F. Raffa. 2008. Parasitoids and dipteran predators exploit volatiles from microbial symbionts to locate bark beetles. Environ. Entomol. 37: 150-161.

Chesson, P. 2000. Mechanisms of maintenance of species diversity. Annu. Rev. Ecol. Syst. 31: 343-366.

Cortesero, A. M., C. M. De Moraes, J. O. Stapel, J. H. Tumlinson, and W. J. Lewis. 1997. Comparisons and contrasts in host foraging strategies of two larval parasitoids with different degrees of host specificity. J. Chem. Ecol. 23: 1589-1606.

Crespo, D. C., R. E. Lecuona, and J. A. Hogsette. 2002. Strategies for controlling house fly populations resistant to cyromazine. Neotrop. Entomol. 31: 141-147.

Davis, T. S., T. L. Crippen, R. W. Hofstetter, and J. K. Tomberlin. 2013. Microbial volatile emissions as insect semiochemicals. J. Chem. Ecol. 39: 840-859.

de Moraes, C. M., W. J. Lewis, P. W. Paré, H. T. Alborn, and J. H. Tumlinson. 1999. Herbivore-infested plants selectively attract parasitoids. Nature 393: 570-573.

Denoth, M., L. Frid, and J. H. Myers. 2002. Multiple agents in biological control: improving the odds? Biol. Control 24 $20-30$.

van Dijken, M. J., and J. J. M. van Alphen. 1998. The ecological significance of differences in host detection behavior in coexisting parasitoid species. Ecol. Entomol. 23: 265-270.

Edwards, R. L. 1954. The host-finding and oviposition behavior of Mormoniella vitripennis (Walker) (Hym. pteromalidae), a parasite of muscoid flies. Behaviour 7: 88-112.

Ehler, L. E., and R. W. Hall. 1982. Evidence for competitive exclusion of introduced natural enemies in biological control. Environ. Entomol. 11: 1-4.

Elzen, G. W., H. J. Williams, and S. B. Vinson. 1983. Response by the parasitoid Campoletis sonorensis (Hymenoptera: lchneumonidae) to chemicals (synomones) in plants: implications for host habitat location. Environ. Entomol. 12: 1873-1877.

Geden, C. J. 2002. Effect of habitat depth on host location by five species of parasitoids (Hymenoptera: Pteromalidae, Chalcididae) of house flies (Diptera: Muscidae) in three types of substrates. Environ. Entomol. 31: 411-417.

Geden, C. J., and J. A. Hogsette. 2006. Supporession of house flies (Diptera: Muscidae) in Florida poultry houses by sustained releases of Muscidifurax raptorellus and Spalangia cameroni (Hymenoptera: Pteromalidae). Environ. Entomol. 35: $75-82$.

Geden, C. J., L. Smith, S. J. Long, and D. A. Rutz. 1992. Rapid deterioration of searching behavior, host destruction, and fecundity of the parasitoid Muscidifurax raptor (Hymenoptera: Pteromalidae) in culture. Ann. Entomol. Soc. Am. 85: 179-187.

Geervliet, J. B. F., L. E. M. Vet, and M. Dicke. 1996. Innate responses of the parasitoids Cotesia glomerata and C. rubecula (Hyenoptera: Braconidae) to volatiles from different plant-herbivore complexes. J. Insect Behav. 9: 525-538.

Gerling, D., and E. F. Legner. 1968. Developmental history and reproduction of Spalangia cameroni, parasite of synanthropic flies. Ann. Entomol. Soc. Am. 61: 1436-1443.

Godfray, H. C. J. 1994. Parasitoids: behavioral and evolutionary ecology. Princeton University Press, Princeton, NJ.

Harvey, J. A., E. H. Poelman, and T. Tanaka. 2013. Intrinsic inter- and intraspecific competition in parasitoid wasps. Annu. Rev. Entomol. 58: 333-351.

King, B. H. 1990. Sex ratio manipulation by the parasitoid wasp Spalangia cameroni in response to host age: a test of the hostsize model. Evol. Ecol. 4: 149-156.

King, B. H. 1997. Effects of age and burial of house fly pupae (Diptera: Muscidae) on parasitism by Spalangia cameroni and Muscidifurax raptor (Hymenoptera: Pteromalidae). Environ Entomol. 26: 410-415. 
King, B. H., and R. B. King. 1994. Sex-ratio manipulation in response to host size in the parasitoid wasp Spalangia cameroni - is it adaptive? Behav. Ecol. 5: 448-454.

Laing, J. 1937. Host finding by insect parasites. I. Observations on the finding of hosts by Alysia manducator, Mormoniella vitripennis and Trichogramma evanescens. J. Anim. Ecol. 6: 298-317.

Legner, E. F. 1977. Temperature, humidity and depth of habitat influencing host destruction and fecundity of muscoid fly parasites. Entomophaga 22: 199-206.

Machtinger, E. T. 2011. Studies on the field ecology, breeding biology and parasitism of house flies, Musca domestica, and stable flies, Stomoxys calcitrans, (Diptera: Muscidae) to improve integrated pest management for North Florida small equine farms. Masters thesis, University of Florida, Gainesville, FL.

Machtinger, E. T., and C. J. Geden. 2013. Host location by Spalangia cameroni (Hymenoptera: Pteromalidae) in equine associated substrates. Biol. Control 65: 130-134.

Machtinger, E. T., N. C. Leppla, and C. S. Sanders. 2012. Pest management perceptions and practices for equine farms in North and Central Florida. EDIS Publication ENY-2028. University of Florida, Institute of Food and Agricultural Sciences, Gainesville, FL.

Mandeville, J. D., and B. A. Mullens. 1990. Host preference and learning in Muscidifurax zaraptor (Hymenoptera: Pteromalidae). Ann. Entomol. Soc. Am. 83: 1203-1209.

Mandeville, J. D., B. A. Mullens, and J. A. Meyer. 1988. Rearing and host age suitability of Fannia canicuaris (L.) (Diptera: Muscidae) for parasitization by Muscidifurax zaraptor Kogan and Legner (Hymenoptera: Pteromalidae) Can. Entomol. 120: 153-159.

Mbata, G. N., S. Shu, T. W. Phillips, and S. B. Ramaswamy. 2004. Semiochemical cues used by Pteromalus cerealellae (Hymenoptera: Pteromalidae) to locate its host, Callosobruchus maculates (Coleoptera: Bruchidae). Ann. Entomol. Soc. Am. 97: 353-360.

Mckay, T., and A. B. Broce. 2003. Response of Muscidifurax zaraptor (Hymenoptera: pteromalidae) to olfactory stimuli from hosts and their habitat. J. Kans. Entomol. Soc. 76: $31-37$.

McKay, T., and T. D. Galloway. 1999. Survey and release of parasitoids (Hymenoptera) attacking house and stable flies (Diptera: Muscidae) in dairy operations. Can. Entomol. 131: 743-756.

McKay, T., C. D. Steelman, S. M. Brazil, and A. L. Szalanski. 2007. Sustained mass release of pupal parasitoids (Hymenoptera: Pteromalidae) for control of Hydrotaea aenescens and Musca domestica (Diptera: Muscidae) in broiler-breeder poultry houses in Arkansas. J. Agric. Urban Entomol. 24: 67-85.

Meyer, J. A., B. A. Mullens, T. L. Cyr, and C. Stokes. 1990. Commercial and naturally occurring fly parasitoids (Hymenoptera: Pteromalidae) as biological control agents of stable flies and house flies (Diptera: Muscidae) on California dairies. J. Econ. Entomol. 83: 799-806.

Morgan, P. B., and R. S. Patterson. 1990. Efficiency of target formulations of pesticides plus augmentative releases of Spalangia endius Walker (Hymenoptera: Pteromalidae) to suppress populations of Musca domestica L. (Diptera: Muscidae) at poultry ranches in the southeastern United States, pp. 69-78. In D. A. Rutz and R. S. Patterson (eds.), Biocontrol of arthropods affecting livestock and poultry. Westview, Boulder, CO.

Morgan, P. B., H. Hoyer, and R. S. Patterson. 1989. Life history of Spalangia cameroni Perkins (Hynenoptera: Pteromalidae), a microhymenopteran pupal parasitoid of moscoid flies. (Diptera: Muscidae). J. Kans. Entomol. Soc. 62: 381-386.
Myers, J. H., C. Higgins, and E. Covacs. 1989. How many insect species are necessary for the biological control of insects? Environ. Entomol. 18: 541-547.

Myint, W. W., and G. H. Walter. 1990. Behaviour of Spalangia cameroni males and sex ratio theory. Oikos 59: 163-174.

Noldus, L. P. 1988. Response of the egg parasitoid Trichogramma pretiosum to the sex pheromone of its host Heliothis zea. Entomol. Exp. App. 48: 293-300.

Noyes, J. S. 2014. Universal Chalcidoidea Database. World Wide Web electronic publication. (http://www.nhm.ac.uk/ chalcidoids) (accessed 16 July 2014).

Omacini, M., E. J. Chaneton, C. M. Ghersa, and C. B. Muller. 2001. Symbiotic fungal endophytes control insect host-parasite interaction webs. Nature 409: 78-81.

Petersen, J. J., and D. W. Watson. 1992. Comparison of sentinel and naturally occurring fly pupae to measure field parasitism by pteromalid parasitoids (Hymenoptera). Biol. Control 2: $244-248$.

Petersen, J. J., and J. K. Cawthra. 1995. Release of a gregarious Muscidifurax species (Hymenoptera: pteromalidae) for the control of filth flies associated with confined beef cattle. Biol. Control 5: 279-284.

Pitzer, J. B., P. E. Kaufman, C. J. Geden, and J. A. Hogsette. 2011. The ability of selected pupal parasitoids (Hymenoptera: Pteromalidae) to locate stable fly hosts in soiled equine bedding substrate. Environ. Entomol. 40: 88-93.

Rueda, L. M., and R. C. Axtell. 1985. Effect of depth of house fly pupae in poultry manure on parasitism by six species of Pteromalidae (Hymenoptera). J. Entomol. Sci. 20: $444-449$.

Schulz, S., and J. S. Dickschat. 2007. Bacterial volatiles: the smell of small organisms. Nat. Prod. Rep. 24: 814-842.

Skovgård, H. 2006. Search efficiency of Spalangia cameroni and Muscidifrax raptor on Musca domestica pupae in dairy cattle farms in Denmark. Biocontrol 51: 49-64.

Skovgård, H., and G. Nachman. 2004. Biological control of house flies Musca domestica and stable flies Stomoxys calcitrans (Diptera: Muscidae) by means of inundative releases of Spalangia cameroni (Hymenoptera: pteromalidae). Bull. Entomol. Res. 94: 555-567.

Stafford, K. C., III, C. W. Pitts, and T. L. Webb. 1984. Olfactometer studies of host seeking by the parasitoid Spalangia endius Walker (Acari: Macrochelidae) Environ. Entomol. 13: 228-231.

Steidle, J. L. M., and M. Schöller. 1997. Olfactory host location and learning in the granary weevil parasitoid Lariophagus distinguendus (Hymenoptera: Pteromalidae). J. Insect Behav. 10: 331-342.

Steidle, J. L. M., and M. Schöller, 2002. Fecundity and ability of the parasitoid Lariophagus distinguendus (Hymenoptera: Pteromalidae) to parasitize larvae of the granary weevil Sitophilus granaries (Coleoptera: Curculionidae) in bulk grain. J. Stored Prod. Res. 38: 43-53.

Steiner, S., D. Erdmann, J.L.M. Steidle, and J. Ruther. 2007, Host habitat assessment by a parasitoid using fungal volatiles. Front. Zool. 4: 3-9.

Taylor, D. B., R. Moon, G. Gibson, and A. Szalanski. 2006. Genetic and morphological comparisons of new and old world populations of Spalangia species (Hymenoptera:Pteromalidae). Ann. Entomol. Soc. Am. 99: 799-808.

(USDA) United States Department of Agriculture. 2006. Equine 2005, Part II: Changes in the U.S. Equine Industry, 1998-2005 USDA-APHIS-VS, CEAH. Fort Collins, CO.

Vet, L. E. M., F. L. Wäckers, and M. Dicke, 1991. How to hunt for hiding hosts: the reliability-detectability problem for foraging parasitoids. Neth. J. Zool. 41: 202-213.

Vet, L. E. M., M. B. Sokolowski, D. E. MacDonald, and H. Snellen. 1993. Responses of a generalist and a 
specialist parasitoid (Hymenoptera: Eucoilidae) to drosophilid larval kairomones. J. Insect Behav. 6: 615-624.

Vinson, S. B. 1976. Host selection by insect parasitoids. Annu. Rev. Entomol. 21: 109-134.

Vinson, S. B. 1981. Habitat location. In D. A. Nordlund, W. J. Lewis, and R. L. Jones (eds.), Semiochemicals: their role in pest control. John Wiley and Sons, New York, NY pp. 51-78.

Voss, S. C., H. Spafford, and I. R. Dadour. 2009. Hymenopteran parasitoids of forensic importance: host associations, seasonality, and prevalence of parasitoids of carrion flies in Western Australia. J. Med. Entomol. 46: 1210-1219.

Weinzierl, R. A., and C. J. Jones. 1998. Releases of Spalangia nigroaenea and Muscidifurax zaraptor
(Hymenoptera: Pteromalidae) increase rates of parasitism and total mortality of stable fly and house fly (Diptera: Muscidae) puparia in Illinois cattle feedlots. J. Econ. Entomol. 91: 1114-1121.

Wiskerke, J. S. C., and L. E. M. Vet. 1994. Foraging for solitarily and gregariously feeding caterpillars: a comparison of two related parasitoid species (Hymenoptera: Braconidae). J. Insect Behav. 7: 585-603.

Wylie, H. G. 1958. Factors that affect host finding by Nasonia vitripennis (Walk) (Hymenoptera:pteromalidae). Can. Entomol. 90: 597-608.

Received 30 July 2014; accepted 9 December 2014. 